Su and J.M. Trent. 1996. Use of a cDNA microarray to analyze gene expression patterns in human cancer. Nature Genet. 14:457-460.

6.Feinberg, A.P. and B. Vogelstein. 1983. A technique for radiolabeling DNA restriction endonuclease fragments to high specific activity. Anal. Biochem. 132:6-13.

7.Horstmann, H.J., J.W. Rohen and K. Sames. 1983. Age-related changes in the composition of proteins in the trabecular meshwork of the human eye. Mech. Ageing Dev. 21:121-136.

8.Jordan, B.R. 1998. Large-scale expression measurement by hybridization methods: from high density membranes to "DNA chips". J. Biochem. 124:251-258.

9.Lennon, G., C. Auffray, M. Polymeropoulos and M.B. Soares. 1996. The I.M.A.G.E. consortium: an integrated molecular analysis of genomes and their expression. Genomics 33:151-152.

10.Nguyen, C., D. Rocha, S. Granjeaud, M. Baldit, K. Bernard, P. Naquet and B.R. Jordan. 1995. Differential gene expression in the murine thymus assayed by quantitative hybridization of arrayed cDNA clones. Genomics 29:207-216.

11.Patel, P.H. and B.D. Preston. 1994. Marked infidelity of human immunodeficiency virus type 1 reverse transcriptase at RNA and DNA template ends. Proc. Natl. Acad. Sci. USA 91:549-553.

12.Pietu, G., O. Alibert, V. Guichard, B. Lamy, F. Bois, E. Leroy, R. Mariage-Sampson, R. Houlgatte, P. Soularue and C. Auffray. 1996. Novel gene transcripts preferentially expressed in human muscles revealed by quantitative hybridization of a high density cDNA array. Genome Res. 6:492-503.

13.Schena, M., D. Shalon, R.W. Davis and P.O. Brown. 1995. Quantitative monitoring of gene expression patterns with a complementary DNA microarray. Science 270:467-470.

14.Schena, M., D. Shalon, R. Heller, A. Chai, P.O. Brown and R.W. Davis. 1996. Parallel human genome analysis: microarray-based expression monitoring of 1000 genes. Proc. Nat. Acad. Sci. USA 93:10614-10619.

15.Stamer, W.D., R.E. Seftor, S.K. Williams, H.A. Samaha and R.W. Snyder. 1995. Isolation and culture of human trabecular meshwork cells by extracellular matrix digestion. Curr. Eye Res. 14:611-617.

This work was supported by National Eye Institute Grant Nos. EY11906 and EY01894, the American Health Assistance Foundation and the Research to Prevent Blindness. T.B. is a Jules and Doris Stein Research to Prevent Blindness Professor Awardee. Address correspondence to Dr. Teresa Borrás, Duke University Medical Center, Wadsworth Building, Erwin Road, Box 3802, Durham, NC 27710, USA. Internet: borra001@mc.duke.edu

Received 17 September 1998; accepted 2 February 1999.

\author{
Pedro Gonzalez, J. Samuel \\ Zigler, Jr. ${ }^{1}$, David L. Epstein \\ and Teresa Borrás \\ Duke University Medical Center \\ Durham, NC \\ ${ }^{1}$ National Eye Institute \\ NIH, Bethesda, MD, USA
}

\section{Increasing DNA Transfer Efficiency by Temporary Inactivation of Host Restriction}

BioTechniques 26:892-900 (May 1999)

\section{ABSTRACT}

E. coli and Salmonella typhimurium are widely used bacterial hosts for genetic manipulation of DNA from prokaryotes and eukaryotes. Introduction of foreign DNA by electroporation or transduction into $\mathrm{E}$. coli and Salmonella is limited by host restriction of incoming DNA by the recipient cells. Here, we describe a simple method that temporarily inactivates host restriction, allowing high-frequency DNA transfer. This technique might be readily applied to a wide range of bacteria to increase DNA transfer between strains and species.

\section{INTRODUCTION}

Molecular biology relies on the ability to efficiently introduce foreign DNA into different hosts. Cloned DNA from bacteria, eukaryotes and archea is routinely moved into bacterial hosts for subsequent manipulations. The efficiency of acquisition of foreign DNA is limited by host restriction, the ability of the recipient strain to distinguish incoming DNA from its own chromosome and, preferentially, digest the invading DNA. Escherichia coli and Salmonella possess potent type I restriction modification systems $(4,10)$. These systems comprise three proteins. HsdS is the subunit that recognizes the specific DNA sequences that are to be methylated or restricted. Methylation by HsdM marks the DNA as belonging to the host and prevents it from being digested by the restriction subunit, HsdR. Naive DNA entering a bacterium is not methylated and is digested by HsdR. The restriction activity results in linear double-stranded (ds)DNA, which is rapidly degraded by the RecBCD complex (15). With a very low frequency, HsdM modifies unmethylated DNA before it is restricted by HsdR. The resulting methylated DNA is replicated and recognized as host DNA in future bacterial generations.

In the laboratory, host restriction hinders the introduction of novel DNA, such as phage or plasmids, into bacterial strains and limits the construction of mutants and their analysis. Many of the common laboratory E. coli strains used for recombinant DNA experiments contain mutations that prevent restriction ( $r^{-}$strains). In contrast, restriction deficient derivatives of most other species of bacteria are not available. Thus, host restriction must be overcome before foreign DNA can be efficiently introduced into these strains.

Plasmids can be moved between strains by conjugation, and it has previously been shown that the efficiency of DNA transfer by conjugation between Salmonella and E. coli can be increased by a simple heat treatment (9). In this report, we describe the use of heat treatment to temporarily and specifically inactivate the restriction subunit of type I restriction modification complexes in enteric bacteria, thereby allowing high-efficiency introduction of foreign DNA into wild-type $r^{+}$strains. We show that this technique is equally applicable to E. coli and Salmonella strains and might also be widely used to enhance the efficiency of DNA transfer into other bacterial species.

\section{MATERIALS AND METHODS}

\section{Strains and Phage}

Table 1 describes all strains and phage used in this study. To isolate phage with altered modification phenotypes, high-titer lysates were streaked on the appropriate host growing in a top 
agar plate. Individual plaques were used to inoculate cultures for high-titer lysates (7).

\section{Bacterial Growth Conditions}

Bacteria were grown in LB medium (7). When antibiotics were required, they were added at the following final concentrations: $30 \mu \mathrm{g} / \mathrm{mL}$ ampicillin, 10 $\mu \mathrm{g} / \mathrm{mL}$ tetracycline, $45 \mu \mathrm{g} / \mathrm{mL}$ kanamycin and $30 \mu \mathrm{g} / \mathrm{mL}$ chloramphenicol.

\section{Inactivation of Host Restriction}

Phage titers and transductions. Immediately before transduction, 0.1 $\mathrm{mL}$ of an overnight culture of bacteria was heated to $50^{\circ} \mathrm{C}$ in an $0.5-\mathrm{mL}$ polymerase chain reaction (PCR) tube in a PTC-100 TM Thermal Cycler (MJ Research, Watertown, MA, USA). For phage titers and efficiency of plating (EOP) calculations, the bacteria were mixed with $5 \mathrm{~mL}$ of top-agar (7) held at $50^{\circ} \mathrm{C}$ and immediately poured onto the surface of a room-temperature LB plate. The agar solidified within $3 \mathrm{~min}$. EOP was determined by titering phage lysates as follows: 10-fold dilutions of a high-titer phage lysate were made from $10^{1}-10^{8}$ in sterile $0.85 \% \mathrm{NaCl}$ solution, then $10 \mu \mathrm{L}$ of each dilution were spotted onto the surface of a top-agar plate. Transductions were performed using the delayed expression technique (7). Briefly, $0.1 \mathrm{~mL}$ of bacteria was mixed with enough phage to give a multiplicity of infection (MOI) between 0.1 and 1 . After a 20-min incubation at $37^{\circ} \mathrm{C}, 1 \mathrm{~mL}$ of LB supplemented with $10 \mathrm{mM}$ EGTA was added, and the samples were incubated for an additional $20 \mathrm{~min}$ at $37^{\circ} \mathrm{C}$. The samples were concentrated by centrifugation, resuspended in $0.1 \mathrm{~mL}$ of $\mathrm{LB}$ and spread on selective plates. All plates were incubated overnight at $37^{\circ} \mathrm{C}$. All EOPs and transduction frequencies are the average of at least two independent experiments.

Electroporations. Before electroporation, $0.3 \mathrm{~mL}$ of a mid-log phase culture was incubated at $50^{\circ} \mathrm{C}$ as described above. Following heat treatment, the sample was cooled on ice for $2 \mathrm{~min}$, and the cells were made competent by washing three times with icecold sterile $10 \%$ glycerol. Electropora-

Table 1. Strains, Plasmids and Phage Used in this Study

\begin{tabular}{|llc|}
\hline Strain & Restriction Phenotype & Reference \\
\hline $\begin{array}{l}\text { Salmonellae: } \\
\text { S. typhimurium LT2 }\end{array}$ & $\left(\mathrm{r}^{+} \mathrm{m}^{+}\right)_{\mathrm{LT}}\left(\mathrm{r}^{+} \mathrm{m}^{+}\right)_{\mathrm{LTII}}\left(\mathrm{r}^{+} \mathrm{m}^{+}\right)_{\mathrm{LTIII}}$ & $(16)$ \\
S. typhimurium JS107 & $\left(\mathrm{r}^{+} \mathrm{m}^{+}\right)_{\mathrm{LT}}\left(\mathrm{r}^{+} \mathrm{m}^{+}\right)_{\mathrm{LTII}}\left(\mathrm{r}^{+} \mathrm{m}^{+}\right)_{\mathrm{LTIII}}$ zjg::Kan & $(8)$ \\
S. enteritidis LK5 & $\left(\mathrm{r}^{+} \mathrm{m}^{+}\right)_{\mathrm{SEN}}\left(\mathrm{r}^{+} \mathrm{m}^{+}\right)_{\mathrm{LT}}\left(\mathrm{r}^{+} \mathrm{m}^{+}\right)_{\mathrm{LTIII}}$ & $(6)$ \\
E. coli: & & \\
E. coli K-12 MG1655 & $\left(\mathrm{r}^{+} \mathrm{m}^{+}\right)_{\mathrm{K}}$ & $(5)$ \\
E. coli C & $\left(\mathrm{r}^{-} \mathrm{m}^{-}\right)$ & $(3)$ \\
Phage: & & \\
P22 $(\mathrm{St})$ & $\mathrm{P} 22 \mathrm{HT}$ int modified by S. typhimurium & $(12)$ \\
P22 $(\mathrm{Se})$ & $\mathrm{P} 22 \mathrm{HT}$ int modified by S. enteritidis & $(12)$ \\
$\lambda$ vir $(\mathrm{K})$ & E. coli K modified $\lambda$ & $(13)$ \\
$\lambda$ vir $(\mathrm{C})$ & unmodified $\lambda$ & $(13)$ \\
aAll strains are prototrophic. & \\
\hline
\end{tabular}

tions were performed immediately in 1.5-mm cuvettes. The time constant was approximately $4 \mathrm{kV}$ using a Gene Pulser ${ }^{\circledR}$ Electroporator (Bio-Rad, Hercules, CA, USA). Bacteria were then diluted in $1 \mathrm{~mL}$ room-temperature $\mathrm{LB}$ and incubated at $37^{\circ} \mathrm{C}$ for $1 \mathrm{~h}$ to allow expression of the antibiotic-resistance gene encoded by the plasmid. Following centrifugation, samples were resuspended in $0.1 \mathrm{~mL}$ of LB and spread on selective plates. All electroporation frequencies are the average of at least two independent experiments.

Viable counts. The viability of each culture was assayed before and after each heat treatment. Viable counts were measured by diluting bacteria in sterile $0.85 \% \mathrm{NaCl}$ and spotting $10 \mu \mathrm{L}$ of each dilution onto an LB plate. The spot was allowed to dry at room temperature, and the plate was incubated overnight at $37^{\circ} \mathrm{C}$. All viable counts are the average of at least two independent experiments.

\section{RESULTS AND DISCUSSION}

\section{Effect of Heat Treatment on Viability}

A previous report indicated that mild heat pretreatment might increase the conjugation frequency between $E$. coli and S. typhimurium (14-16). However, there was no indication whether this treatment would increase the fre- quency of interspecies transduction or electroporation, or whether it could be extended to other enteric bacteria in addition to $S$. typhimurium. Therefore, we examined the effect of temperature on overcoming restriction barriers to phage infection or electroporation of plasmids in enteric bacteria.

To examine the effect of heat treatment on host restriction, we first needed to determine the viability of the recipients at different temperatures. Figure 1 shows the survival of $S$. enteritidis and $S$. typhimurium after heating to $50^{\circ}$ and $60^{\circ} \mathrm{C}$. At $60^{\circ} \mathrm{C}$, the majority of the Salmonella were killed within the first $5 \mathrm{~min}$, and viability was completely lost by $30 \mathrm{~min}$. In contrast, at $50^{\circ} \mathrm{C}$, the viability decreased much slower, such that after $1 \mathrm{~h}$ at $50^{\circ} \mathrm{C}$, the loss was less than 2 logs. The decrease in viability did not appear to be related to the growth phase of the culture. Because brief heat treatment at $60^{\circ} \mathrm{C}$ is lethal to Salmonella, the effect of higher temperatures on host restriction was not assessed. In contrast, heating to $40^{\circ} \mathrm{C}$ for up to $1 \mathrm{~h}$ had no effect on either the viability or host restriction by Salmonella (data not shown).

\section{Effect of Heat Treatment on Host Restriction}

Transfer of DNA between Salmonella species (intraspecies transfer). Previously, it has been shown that $S$. 


\section{Short Technical Reports}

Table 2. Effect of Restriction Modification Systems on EOP of P22

\begin{tabular}{|llc|}
\hline & \multicolumn{2}{c|}{$\begin{array}{c}\text { EOP of Donor } \\
\text { Phage }\end{array}$} \\
\cline { 2 - 3 } Recipient & $\mathbf{P 2 2}_{\text {(St) }}$ & $\mathbf{P 2 2}_{\text {(Se) }}$ \\
\hline S. typhimurium & 1.0 & 0.4 \\
S. enteritidis & 0.0003 & 1.0 \\
\hline
\end{tabular}

enteritidis and $S$. typhimurium share some restriction systems (4). The three host restriction systems of $S$. typhimurium are the LT, LTII and LTIII (also called the LT, SA and SB systems, respectively) $(2,4)$. S. enteritidis contains the LT and LTIII systems (but not the LTII system) and also contains a unique restriction system, the SEN system. The efficiencies with which Salmonella restricted phage infections were not equal (Table 2). The SEN system restricted $\mathrm{P} 22_{(\mathrm{St})}\left(\mathrm{SEN}^{-}\right)$approximately 4 to $5 \operatorname{logs}$, but the LTII restriction system restricted P22 $(\mathrm{Se})$ (LTII-) approximately one $\log (4)$.

The titer of either P22 $(\mathrm{St})$ or P22 $(\mathrm{Se})$ on $S$. typhimurium was not affected by heating (Figure 2A). In contrast, heating $S$. enteritidis to $50^{\circ} \mathrm{C}$ inactivated the potent SEN restriction system (Figure 2B). The inactivation of the SEN restriction system was maximal after approximately $20 \mathrm{~min}$. From $20 \mathrm{~min}$ to 1 $\mathrm{h}$, there was no significant loss of viability (Figure 1) and only minor changes in restriction inactivation. During the first $20 \mathrm{~min}$ that the recipient was heated, the phage titer decreased in parallel with the loss of bacterial viability (Figure 1). Because the phage were not heated, and the decrease in titer was observed for both P22 and $\lambda v i r$, this decrease in titer is likely to be the result of phage adsorption to bacteria that have been killed by heating, thereby preventing a productive infection.

Heat treatment only affected the restriction system of $S$. enteritidis and did not affect DNA entry into the cell or recombination into the chromosome. The frequency with which a kanamycin-resistance marker was transferred between $S$. typhimurium and $S$. enteritidis was restored to the same level as for transfer between $S$. typhimurium and $S$. typhimurium following heat treatment

Table 3. Effect of Heat Pretreatment on Transduction Efficiency

\begin{tabular}{|lcc|}
\hline & \multicolumn{2}{c|}{ Colonies Recovered } \\
\cline { 2 - 3 } Recipient & No Treatment & $\mathbf{5 0}^{\circ} \mathbf{C}$ Pretreatment \\
\hline S. enteritidis & 0 & 133 \\
S. typhimurium & 168 & 142 \\
The kan R marker from JS107 (S. typhimurium modified) was transduced into \\
S. typhimurium and S. enteritidis.
\end{tabular}

Table 4. Effect of Heating E. coli on the EOP of $\lambda$ vir

\begin{tabular}{|cccccc|}
\hline & \multicolumn{2}{c}{$\lambda$ vir $_{(\mathrm{K})}$ EOP } & & \multicolumn{2}{c|}{$\lambda$ vir $_{(\mathrm{C})}$ EOP } \\
\cline { 2 - 3 } \cline { 5 - 6 } E. coli Strain & Not Heated & Heated & & Not Heated & Heated \\
\hline $\mathrm{K}$ & 1 & 1 & & 0.01 & 1 \\
$\mathrm{C}$ & 0.7 & 0.4 & & 1 & 1 \\
\hline
\end{tabular}

of the recipient strain (Table 3 ).

These results demonstrate two differences in host restriction in S. enteritidis and S. typhimurium: (i) The LTII restriction system is present in $S$. typhimurium but not in $S$. enteritidis. This is a relatively weak restriction system that reduces unmodified phage titers by approximately one $\log$ and is not affected by temperature (Figure 2A). (ii) The SEN restriction system is present in S. enteritidis but not in $S$. typhimurium. This is a more efficient system, which reduces unmodified phage titers by 4 to $5 \operatorname{logs}$, and, unlike the LTII system, is inactivated by tempera-

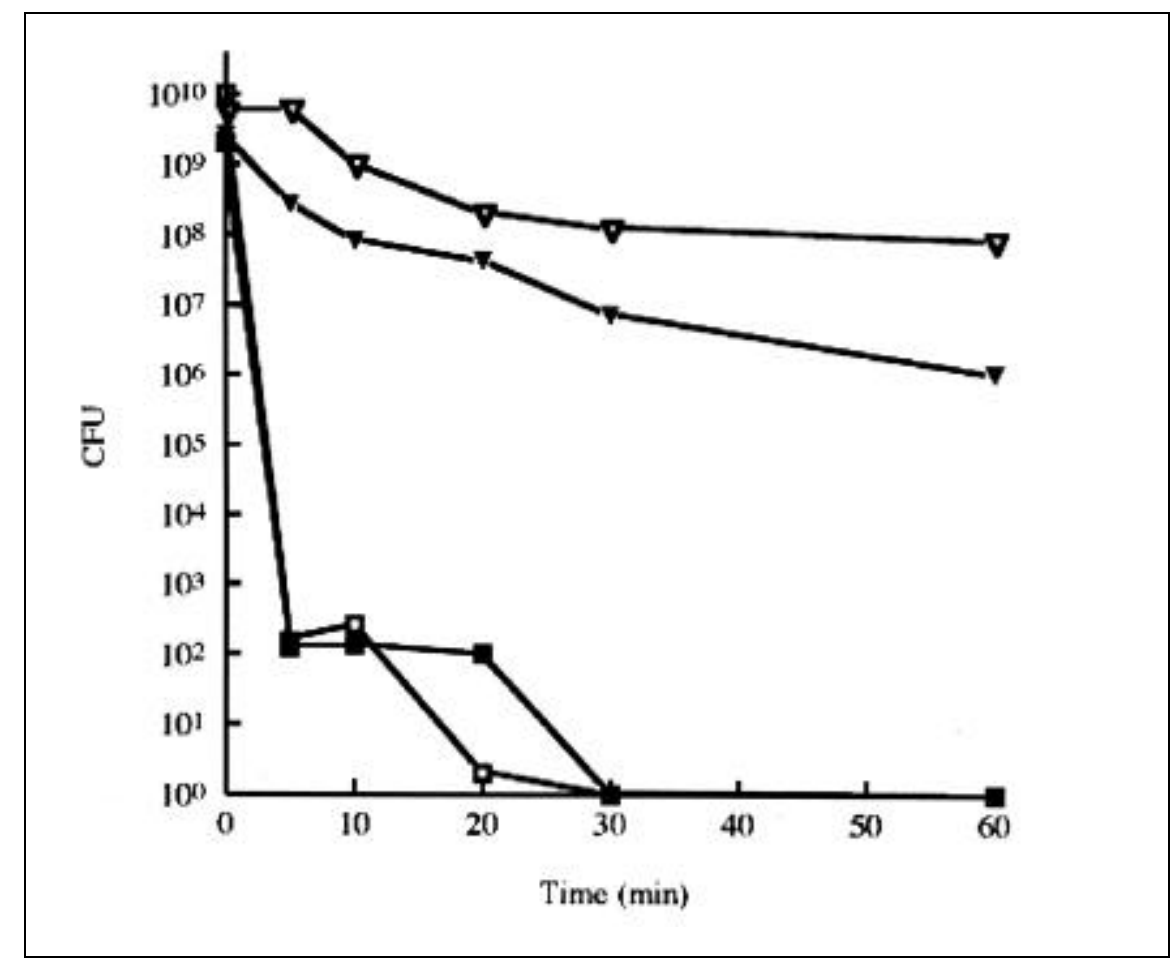

Figure 1. Survival of S. typhimurium and $S$. enteritidis at $50^{\circ}$ and $60^{\circ} \mathrm{C}$. Viability of $S$. typhimurium (open symbols) and $S$. enteritidis (filled symbols) were assessed after incubation at $50^{\circ}$ (triangles) or $60^{\circ} \mathrm{C}$ (squares) for up to $1 \mathrm{~h}$. 


\section{Short Technical Reports}

ture treatment (Figure 2B).

DNA transfer between $E$. coli strains (intraspecies transfer). Two $E$. coli strains have different restriction and modification phenotypes. E. coli K strains have a functional restriction system, but $E$. coli $\mathrm{C}$ strains are phenotypically $\mathrm{r}^{-} \mathrm{m}^{-}$(1). To analyze host restriction in $E$. coli, we assayed the titer of differentially modified $\lambda v i r$ lysates. When $E$. coli $\mathrm{K}$ was infected with $\lambda$ vir grown in $E$. coli $\mathrm{C}$, host restriction decreased the EOP by 2 logs. However, as described for Salmonella, pretreatment of $E$. coli $\mathrm{K}$ for $30 \mathrm{~min}$ at $50^{\circ} \mathrm{C}$ was sufficient to inactivate the restriction system (Table 4).

Transfer of DNA between $E$. coli and Salmonella (interspecies transfer). The method of choice for introducing DNA into many bacterial species is electroporation. Therefore, we used interspecies DNA transfer to assay the effect of heat treatment on Salmonella host restriction following electroporation. After heat treatment, the cell viability decreased by approximately 2 logs, similar to that shown in Figure 1. However, the additional treatments involved in electroporation (both making

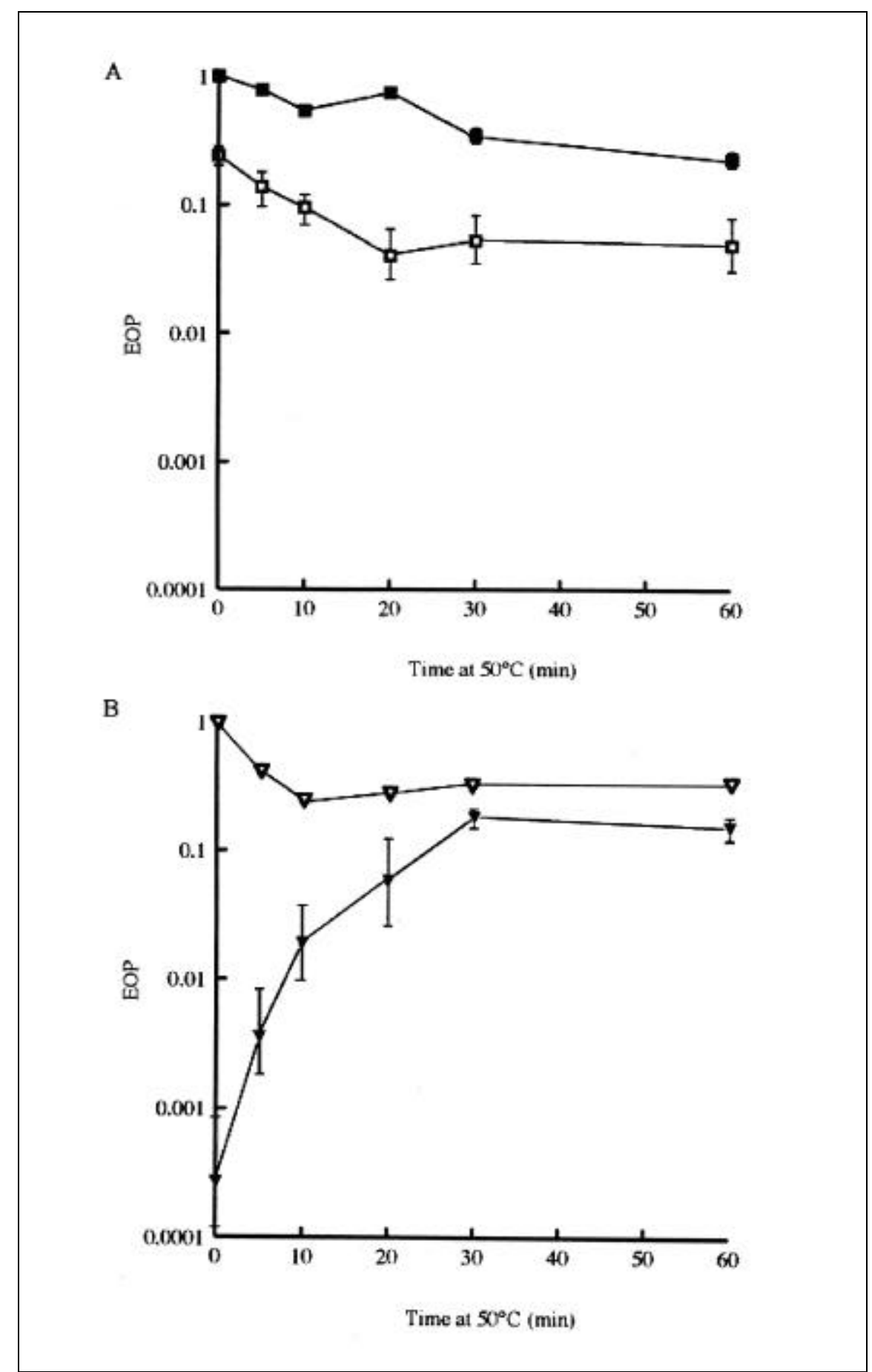

Figure 2. Effect of heating S. typhimurium and S. enteritidis on $\mathrm{P22}_{(\mathrm{St})}$ and $\mathrm{P22}(\mathrm{Se})$ titers. The EOP of $\mathrm{P} 22_{(\mathrm{St})}$ (closed symbols) and $\mathrm{P} 22_{(\mathrm{Se})}$ (open symbols) on (A) S. typhimurium and (B) S. enteritidis following heat treatment at $50^{\circ} \mathrm{C}$ for up to $1 \mathrm{~h}$. competent cells and the electric shock) had little effect on cell viability. DNA of a pBR322 plasmid derivative was modified in the E. coli $\mathrm{K}$ strain and then electroporated into the Salmonella strains. Without treatment, host restriction 
Table 5. Effect of Heat Pretreatment on Electroporation Efficiency

\begin{tabular}{|lcc|}
\hline & \multicolumn{2}{c|}{ Colonies Recovered } \\
\cline { 2 - 3 } Recipient & No Treatment & $\mathbf{5 0}^{\circ} \mathbf{C}$ Pretreatment \\
\hline S. typhimurium & 9 & 1800 \\
S. enteritidis & 0 & 2600 \\
E. coli K modified plasmid DNA was transformed into Salmonella. \\
\hline
\end{tabular}

severely reduced the electroporation efficiency of both $S$. enteritidis and $S$. typhimurium; however, after heat treatment at $50^{\circ} \mathrm{C}$ for $30 \mathrm{~min}$, host restriction was effectively inactivated (Table 5).

\section{CONCLUSIONS}

The results indicate that a simple heat treatment of E. coli or Salmonella at $50^{\circ} \mathrm{C}$ results in inactivation of major restriction barriers, allowing the trans- fer of DNA between different strains and species of these enteric bacteria. The stable inheritance of the foreign DNA suggests that the restriction system is either preferentially inactivated or that the modification system is reactivated before the restriction system.

DNA uptake is often detrimental to the recipient. For example, lytic phage can infect a bacterium, reproduce, lyse the cell and subsequently infect other bacteria in the surrounding environment. However, during times of environmental stress, temporary inactivation of host restriction might be beneficial, facilitating horizontal transfer of genes from other bacteria. Such horizontal transfer is proposed to be a driving force in evolution. For example, pathogenesis determinants such as toxins or invasins are frequently transferred as phage, and inheritance of antibiotic resistance is often mediated by transferrable elements such as plasmids or conjugative transposons $(11,14)$.

\section{REFERENCES}

1.Arber, W. and D. Dussoix. 1962. Host specificity of DNA produced by Escherichia coli. I. Host controlled modification of bacteriophage $\lambda$. J. Mol. Biol. 5:18-36.

2.Barcus, V.A. and N.E. Murray. 1995. Barriers to recombination: restriction. In S. Baumberg, J.P.W. Young, J.R. Saunders and E.M.H. Wellington (Eds.), Population Genetics of Bacteria. Cambridge University Press, Cambridge.

3.Bertani, G. and J.J. Weigle. 1953. Host controlled variation in bacterial viruses. J. Bacteriol. 65:113-121.

4.Bullas, L.R., C. Colson and B. Neufeld. 1980. Deoxyribonucleic acid restriction and modification systems in Salmonella: chromosomally located systems of different serotypes. J. Bacteriol. 141:275-292.

5.Guyer, M.S., R.R. Reed, J.A. Steitz and K.B. Low. 1981. Identification of a sex-factor-affinity site in E. coli as gamma delta. Cold Spring Harb. Symp. Quant. Biol.
45:135-140.

6.Keller, L.H., C.E. Benson, K. Krotec and R.J. Eckroade. 1995. Salmonella enteritidis colonization of the reproductive tract and forming and freshly laid eggs of chickens. Infect. Immun. 63:2443-2449.

7.Maloy, S.R., V.J. Stewart and R.K. Taylor. 1996. Genetic Analysis of Pathogenic Bacteria. CSH Laboratory Press, Cold Spring Harbor, NY.

8.Mann, B.A. and J.M. Slauch. 1997. Transduction of low-copy number plasmids by bacteriophage P22. Genetics 146:447-456.

9.Mojica, A.T., and R.B. Middleton. 1971. Fertility of Salmonella typhimurium crosses with Escherichia coli. J. Bacteriol. 108:11611167.

10.Raleigh, E.A. and J.E. Brooks. 1998. Restriction modification systems: where they are and what they do. In G.M. Weinstock (Ed.), Bacterial Genomes. Physical Structure and Analysis. Chapman Hall, New York.

11.Salyers, A.A. and N.B. Shoemaker. 1996. Resistance gene transfer in anaerobes: new insights, new problems. Clin. Infect. Dis. 23:S36-S43.

12.Schmieger, H. 1972. Phage P22-mutants with increased or decreased transduction abilities. Mol. Gen. Genet. 119:75-88.

13.Silhavy, T.J., M.L. Berman and L.W. Enquist. 1984. Experiments with Gene Fusions. CSH Laboratory Press, Cold Spring Harbor, NY.

14.Waldor, M.K. 1998. Bacteriophage biology and bacterial virulence. Trends Microbiol. 6:295-297.

15.Zahrt, T.C. and S. Maloy. 1997. Barriers to recombination between closely related bacteria: $m u t S$ and recBCD inhibit recombination between Salmonella typhimurium and Salmonella typhi. Proc. Natl. Acad. Sci. USA 94:9786-9791.

16.Zinder, N.D. and J. Lederberg. 1952. Genetic exchange in Salmonella. J. Bacteriol. 64:679-699.

We thank Lise Raleigh (New England Biolabs) for helpful suggestions about inactivation of the restriction system and John Cronan, Jr. (University of Illinois at UrbanaChampaign) for the E. coli strains. This work was supported by National Institutes of Health Grant No. PHS GM34715. Address correspondence to Dr. Robert A. Edwards, B103 C\&LSL, Department of Microbiology, University of Illinois at Urbana-Champaign, 601 S. Goodwin Ave, Urbana, IL 61801, USA. Internet: edwards2@uiuc.edu

Received 23 November 1998; accepted 27 January 1999.

Robert A. Edwards, R. Allen Helm and Stanley R. Maloy University of Illinois at UrbanaChampaign

Urbana, IL, USA 